\title{
A comparative study of the teaching and learning of Physical and Human Geography at advanced level in rural secondary schoos in Makonde District in Mashonaland West Province
}

http://dx.doi.org/10.4314/sajest.v3i1.39807

\author{
Mavhura E.", Zinyandu T., Chinyanganya T.P., Manatsa D., Manyani A., Siziba E. \\ Department of Geography, Bindura University of Science Education \\ Private Bag 1020, Bindura, Zimbabwe.
}

*Corresponding Author: E-mail: edmavhura@gmail.com or emavhura@buse.ac.zw

\begin{abstract}
Variations in the Geography 'A' level results for both the Physical and Human Geography components have been noticed in both rural and urban secondary schools. The study examined the causes of the variations in the results by comparing the teaching and learning of Physical and Human Geography in selected secondary schools in Makonde District in Mashonaland West Province. Quantitative as well as qualitative methods of data collection were used. These included questionnaires, in-depth interviews, lesson observations, tests and documentary analysis. The research findings indicated that students performed better in Human than in Physical Geography.This was attributed mainly to teachers who did not adequately cover the Physical Geography component of the syllabus. The results also showed that the other causes for the variations in the results were the shortage of textbooks, lack of libraries and in-service seminars and workshops for Geography teachers. It can therefore be concluded that the variations in the results for Advanced level Geography in rural secondary schools were due to lack of resources and the inadequate coverage of the syllabus by teachers.
\end{abstract}

Keywords: Geography, Human, Learning, Physical, Teaching,

\section{Introduction}

The Ministry of Education, Sports and Culture in Zimbabwe embarked on a policy of offering 'A' level education in previously neglected areas from the year 2002. As a result, many schools in the urban, peri-urban and rural areas were identified for this policy implementation. The identified schools were directed to expand their curricula to include ' $\mathrm{A}$ ' level education. It has been a challenge for these schools to achieve those standards found in some of the schools which started offering ' $A$ ' level education before 2002. This disparity has been noticed in Makonde District by the educational authorities.
The performance of 'A' level Geography students in rural high schools in Makonde District in Mashonaland West Province was poor and many students seeking 'A' level education were shunning these schools. Students were seeking "A" level places in other schools even if it meant paying fees which were higher than those charged by their former ' $\mathrm{O}$ ' level schools. This was evidenced by records kept in the schools. 
This article compared the teaching and learning of Physical and Human Geography at "A" level in three selected secondary schools in Makonde District in Mashonaland West Province. These schools were the only rural schools offering "A" level education in 2002. The purpose of this study was to identify the causes of the variations in the performance of students in Human and Physical Geography. Such research should lead teachers to make informed decisions in teaching (Chikoko and Mhloyi, 1995).

The objectives of the study are as follows:

- To analyse the performance of 'A' level students in Physical and Human Geography from 2003 up to 2006 , and

- To identify the problems faced by both teachers and students in the teaching and learning of Physical and Human Geography.

The article strives to provide answers to the following questions:

- What were the performances of 'A' level students in Physical and Human Geography from 2003 to 2006 ?

- What problems were teachers and students facing in the teaching and learning process of Physical and Human Geography from 2003 to 2006 ?

\section{Research Methodology}

Both quantitative and qualitative methods were used to identify the problems faced by both teachers and students in the teaching and learning of Physical and Human Geography in rural high schools in Makonde District. As a quantitative study, the research is a causal-comparative one which attempts to determine the causes of the existing differences in performances of ' $\mathrm{A}$ ' level students in Physical and Human Geography (Gay, 1976).

This study is also ex post facto since both the effects and the alleged causes had already occurred and were studied in retrospect (McMillan and Schumacher, 1993).
A total of ninety copies of a matrix questionnaire were administered to upper sixth students of 2006 as well as some former ' $\mathrm{A}$ ' level students who had studied Geography between 2003 and 2006 at these schools. The intention was to allow students to open up their experiences in the teaching and learning of Physical and Human Geography. The questionnaire was administered in November 2006 for a month to allow respondents ample time to complete it. To increase its validity, a pilot test of the same questionnaire was first conducted with 'A' level Geography students at one rural high school in the nearby Zvimba District (Opie, 2004; Tuckman, 1988).

Guided formal and informal interviews were done between January and April 2007 to gather data from five teachers. One focused group discussion was conducted with six students drawn from the three schools. Informal interviews were held on various occasions during the same period with the same teachers and students.

A total of thirty Geography lesson observations were carried out at the three schools in order to compare the teaching and learning of Physical and Human Geography as well as to assess the suitability of instructional materials used. Two attainment tests were administered to forty-eight upper sixth students drawn from the three schools. The tests were meant to measure the proficiency of students in Physical and Human Geography (Gwarinda, 2001).

The documents analyzed were the Zimbabwe 'A' level Geography syllabus (9156), the school syllabi of the three schools, the schemes of work, records of marks, students' exercise books, past Zimbabwe School Examinations Council (Zimsec) results analysis and the inventory of resources in the Geography departments of the schools. The objective of analyzing the national syllabus was to identify the topics (both core and options) to be studied along with the practical activities that were supposed to be done. 
These were then compared with the school syllabi, the schemes of work and the exercise books of students. The schemes of work were chosen because they lay down in more detail than the school syllabus, the content that was covered (Gwarinda, 2001). The schemes of work for each group of students from 2003 to 2006 at the three schools were analysed paying special attention to the content, lesson objectives, methods and teaching aids used and the evaluation of each work. This analysis enabled conclusions to be reached on the syllabus coverage and the possibility of selective learning in one component of the subject.

The records of marks of students who completed ' $\mathrm{A}$ ' level Geography between 2003 and 2006 which comprised of assignments, in-class tests and end of term examinations of Physical and Human Geography were analysed.

The analysis gave a general picture of the development of the students in the subject. Students' exercise books revealed the amount and quality of work that was given by the teachers. In this study seven exercise books of the upper sixth Geography students randomly selected from the three schools were analysed.

In order to come up with trends in the pass rate of Geography candidates since 2003, past results of public examinations administered by Zimsec were analysed. Finally, an analysis of the inventory of resources in the Geography department of the three schools was done in order to identify the teaching resources available for use by both teachers and students. In this study the data obtained through the questionnaires and tests were analysed using the Statistical Package for Social Scientists (SPSS Version 16) computer software. The Pearson Correlations and some descriptive statistics of the marks were calculated using this software.
The large volumes of raw data from interviews, lesson observations and documents were analysed manually. The results of the analysis were presented through the use of descriptive statistics to identify themes, significant patterns and relationships among them.

\section{Results and Discussion}

As shown in Table 1, the three schools performed generally well at national examinations from a pass rate point of view. However, the majority of the students in the schools obtained Ds and Es. At one school, no single student had obtained an A between 2003 and 2006. Counts instead of percentages were used to establish the patterns of performance of students because the numbers of candidates who sat for the national examinations were low. These results constituted an average score for both Physical and Human Geography components. This persistently low performance is an indication that either or both of the components could be a problem to both teachers and students. 
Table 1: Analysis of 'A' level Geography Results (2003-2006)

\begin{tabular}{|l|l|l|l|l|l|l|l|l|l|l|l|l|}
\hline \multirow{2}{*}{ GRADE } & \multicolumn{4}{|c|}{ SCHOL A } & \multicolumn{4}{c|}{ SCHOOL B } & \multicolumn{3}{c|}{ SCHOOL C } \\
\cline { 2 - 15 } & $\mathbf{2 0 0 3}$ & $\mathbf{2 0 0 4}$ & $\mathbf{2 0 0 5}$ & $\mathbf{2 0 0 6}$ & $\mathbf{2 0 0 3}$ & $\mathbf{2 0 0 4}$ & $\mathbf{2 0 0 5}$ & $\mathbf{2 0 0 6}$ & $\mathbf{2 0 0 3}$ & $\mathbf{2 0 0 4}$ & $\mathbf{2 0 0 5}$ & $\mathbf{2 0 0 6}$ \\
\hline A & 0 & 0 & 0 & 0 & 0 & 0 & 1 & 0 & 0 & 0 & 1 & 0 \\
\hline B & 1 & 3 & 2 & 2 & 0 & 1 & 0 & 0 & 1 & 2 & 2 & 0 \\
\hline C & 2 & 1 & 4 & 3 & 2 & 1 & 1 & 0 & 1 & 2 & 2 & 1 \\
\hline D & 6 & 5 & 4 & 6 & 5 & 6 & 11 & 7 & 8 & 10 & 4 & 4 \\
\hline E & 7 & 6 & 6 & 3 & 13 & 10 & 9 & 6 & 4 & 3 & 3 & 4 \\
\hline O & 5 & 6 & 8 & 13 & 3 & 3 & 1 & 2 & 2 & 2 & 8 & 3 \\
\hline F & 0 & 3 & 5 & 3 & 1 & 0 & 1 & 0 & 1 & 0 & 1 & 0 \\
\hline $\begin{array}{l}\text { Total No. } \\
\text { of } \\
\text { Candidates }\end{array}$ & 21 & 24 & 29 & 31 & 24 & 21 & 24 & 15 & 17 & 19 & 21 & 11 \\
\hline $\begin{array}{l}\text { No. of } \\
\text { Passes }\end{array}$ & 16 & 15 & 16 & 14 & 20 & 18 & 22 & 13 & 14 & 17 & 12 & 9 \\
\hline \begin{tabular}{l}
$\%$ \\
\hline
\end{tabular} & 76.2 & 62.5 & 55.2 & 45.2 & 83.3 & 85.7 & 91.7 & 86.7 & 82.4 & 89.5 & 54.1 & 81.8 \\
\hline
\end{tabular}

An analysis of data from the school-based assessment records for 2004 for School A, B and C is shown in Tables 2, 3 and 4 respectively. The tables show the Pearson Correlations which were calculated using SPSS (version 16) computer software. In school A there is a negative Pearson Correlation of -0.486 for Physical Geography marks obtained by students whilst there is a weak positive Pearson Correlation of 0.080 for Human Geography marks. When Human and Physical Geography marks for School A were compared, there is a weak positive correlation of 0.273 which shows that students were performing better in Human than in Physical Geography.

Table 2: The Pearson Correlation of the School-based marks at School A in 2004

\begin{tabular}{|c|c|c|c|c|}
\hline - & & $\begin{array}{l}\text { Student } \\
\text { number }\end{array}$ & $\begin{array}{l}\text { Physical } \\
\text { geography } \\
\text { average mark (\%) }\end{array}$ & $\begin{array}{l}\text { Human geography } \\
\text { averag e mark (\%) }\end{array}$ \\
\hline \multirow[t]{3}{*}{$\begin{array}{l}\text { Student } \\
\text { number }\end{array}$} & $\begin{array}{l}\text { Pearson } \\
\text { Correlation }\end{array}$ & 1.000 & -.486 & .080 \\
\hline & Sig. (1 tailed) & - & .008 & .354 \\
\hline & $\mathrm{N}$ & 24 & 24 & 24 \\
\hline \multirow[t]{3}{*}{$\begin{array}{l}\text { Physical } \\
\text { geography } \\
\text { average } \\
\text { mark (\%) } \\
\end{array}$} & $\begin{array}{l}\text { Pearson } \\
\text { Correlation }\end{array}$ & -.486 & 1.000 & .273 \\
\hline & Sig. ( 1 tailed) & -.008 & . & .098 \\
\hline & $\mathrm{N}$ & 24 & 24 & 24 \\
\hline \multirow[t]{3}{*}{$\begin{array}{l}\text { Human } \\
\text { geography } \\
\text { aver age } \\
\text { mark }(\%) \\
\end{array}$} & $\begin{array}{l}\text { Pearson } \\
\text { Correlation }\end{array}$ & .080 & .273 & 1.000 \\
\hline & Sig. (1 tailed) & -.354 & .098 & . \\
\hline & $\mathrm{N}$ & 24 & 24 & 24 \\
\hline
\end{tabular}

Correlation is significant at the 0.01 level (1-tailed). 
In School B as shown in Table 3, a weak positive Pearson Correlation of 0.235 was manifested when marks for Physical Geography were computed. For Human Geography a weak negative correlation of 0.099 is shown
This shows that students performed slightly better in Physical than in Human Geography. When comparing Physical and.Human Geography marks, a strong positive correlation of 0.605 is obtained.

Table 3: The Pearson Correlation of the School-based marks at School B in 2004

\begin{tabular}{|c|c|c|c|c|}
\hline & & $\begin{array}{l}\text { Student } \\
\text { number }\end{array}$ & $\begin{array}{l}\text { Physical } \\
\text { geography } \\
\text { average mark } \\
(\%)\end{array}$ & $\begin{array}{l}\text { Human } \\
\text { geography } \\
\text { average mark (\%) }\end{array}$ \\
\hline \multirow[t]{3}{*}{ Student number } & $\begin{array}{l}\text { Pearson } \\
\text { Correlation }\end{array}$ & 1.000 & .235 & -.099 \\
\hline & Sig. (2 -tailed) & . & .258 & .637 \\
\hline & $N$ & 25 & 25 & 25 \\
\hline \multirow[t]{2}{*}{$\begin{array}{l}\text { Physical } \\
\text { geography } \\
\text { average mark } \\
(\%)\end{array}$} & $\begin{array}{l}\text { Pearson } \\
\text { Correlation }\end{array}$ & .235 & 1.000 & .605 \\
\hline & Sig. (2 -tailed) & .258 & . & .001 \\
\hline \multirow[t]{2}{*}{$\begin{array}{l}\text { Human } \\
\text { geography } \\
\text { average mark } \\
(\%) \\
\end{array}$} & $\begin{array}{l}\text { Pearson } \\
\text { Correlation }\end{array}$ & -.099 & .605 & 1.000 \\
\hline & Sig. (2 -tailed) & .637 & .001 & . \\
\hline
\end{tabular}

Correlation is significant at the 0.01 level (2-tailed). 
In school $\mathrm{C}$ there is a negative Pearson Correlation of -0.158 for Physical Geography marks obtained by students whilst there is a weak positive Pearson Correlation of 0.162 for Human Geography marks.
When Human and Physical Geography marks for School $\mathrm{C}$ were compared, there is a correlation of 0.00 which shows that there is no difference in the performance of students in Human and Physical Geography

Table 4. The Pearson Correlation of the School-based marks at School C in 2004

\begin{tabular}{|c|c|c|c|c|}
\hline 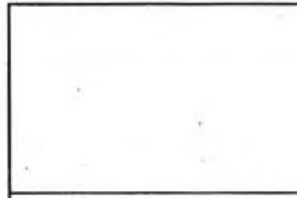 & & $\begin{array}{l}\text { Student } \\
\text { number }\end{array}$ & $\begin{array}{l}\text { Physical } \\
\text { geography } \\
\text { average mark } \\
(\%)\end{array}$ & $\begin{array}{l}\text { Human geography } \\
\text { average mark (\%) }\end{array}$ \\
\hline \multirow[t]{3}{*}{ Student number } & \begin{tabular}{|l} 
Pearson \\
Correlation
\end{tabular} & 1.000 & -.158 & .162 \\
\hline & Sig. (2 -tailed) & . & .412 & .402 \\
\hline & $\mathrm{N}$ & 29 & 29 & 29 \\
\hline \multirow[t]{3}{*}{$\begin{array}{l}\text { Physical } \\
\text { geography } \\
\text { average mark } \\
(\%)\end{array}$} & \begin{tabular}{|l} 
Pearson \\
Correlation
\end{tabular} & -.158 & 1.000 & .000 \\
\hline & Sig. (2 -tailed) & .412 & . & .999 \\
\hline & $\mathrm{N}$ & 29 & 29 & 29 \\
\hline \multirow[t]{3}{*}{$\begin{array}{l}\text { Human } \\
\text { geography } \\
\text { average mark } \\
(\%)\end{array}$} & $\begin{array}{l}\text { Pearson } \\
\text { Correlation }\end{array}$ & .162 & .000 & 1.000 \\
\hline & Sig. (2 -tailed) & .402 & .999 & . \\
\hline & $\mathrm{N}$ & 29 & 29 & 29 \\
\hline
\end{tabular}

In spite of the patterns shown by the three tables, the general trend was that from 2003 to 2006, students performed better in Human than in Physical Geography. These findings are supported by the Examiners' Reports which stated that students performed better in Human than in Physical Geography (Zimsec, 2005).

Interviews and documentary analysis indicated that there was a critical shortage of teaching materials such as textbooks in all three schools as evidenced by the fact that, in School A both upper and lower sixth students were using one textbook: Geography: An Integrated Approach by David Waugh.
This forced teachers to use teacher-directed methods in their teaching and an over-reliance on out-dated books. The results also indicated that Physical Geography was greatly disadvantaged in that one book was shared by both upper and lower sixth students and their respective teachers. Human Geography textbooks were used by a single stream of students at a time. Table 5 shows the number of textbooks available per school against the recommended ones. 
Table 5: Comparison of the recommended textbooks for ' $A$ ' level Geography and the available books at Schools A, B and C.

\begin{tabular}{|l|l|l|l|}
\hline Recommended Textbook & \multicolumn{2}{|l|}{ Number of Books Available } \\
\cline { 2 - 4 } & $\begin{array}{l}\text { School } \\
\text { A }\end{array}$ & $\begin{array}{l}\text { School } \\
\text { B }\end{array}$ & $\begin{array}{l}\text { School } \\
\text { C }\end{array}$ \\
\hline 1. Geography: An Integrated Approach- D. Waugh & 1 & 2 & 1 \\
2. New Patterns: Processes and Change in Human & 2 & 2 & 1 \\
Geography- M. Carr. & 1 & 0 & 0 \\
3. An Introduction to Geomorphology- C. Buckle & 1 & 0 & 0 \\
4. Climate Studies- C. Buckle & 5 & 2 & 0 \\
5. Advanced Geography- E.M. Munowenyu. & 0 & 1 & 0 \\
6. Geomorphology and Hydrology-R.J. Small. & 0 & 0 & 0 \\
7. The Study of Landforms-R.J. Small. & 0 & 1 & 0 \\
8. Techniques and Fieldwork in Geography- Lennon and & & 0 & 0 \\
Cleve & 0 & 0 & 0 \\
9. Practical Geography for Africa-J.M. Pritchard & 0 & 0 & 0 \\
10. Landforms and Landscape in Africa-J.M. Pritchard & 0 & \\
11. Advanced Geography- D. Nagle & 0 & 0 & 0 \\
12. Elements in Human and Economic Geography - W. & & 0 \\
Hammond & 0 & 0 & 0 \\
13. Advanced Physical Geography -D. Briggs &
\end{tabular}

Adapted from Marimo (2005), Unpublished MEd. UZ Thesis.

An analysis of documents such as schemes of work and records of marks supported by evidence from focused group discussions and interviews indicated that there was a paucity of syllabus coverage by the teachers. For instance, in Physical Geography most teachers covered two out of four core topics and one instead of two options recommended by the national syllabus.
In Human Geography only three core topics were taught instead of four and one option was again taught instead of two. This led to selective learning which was based on the accessisibility and availability of instructional materials. In these three schools, the problem was worsened by the organization of the teaching and learning process of 'A' level Geography. 
Physical Geography was given less time of study as students came late in the first term of their Advanced level education. This component was studied during the first year of their curriculum.

The research findings indicated that there was low frequency in the teaching and learning of practical work yet this constituted the compulsory Section A of both examinations papers. This problem was also noted by Namasasu and Samushonga (1996). This has contributed to poor results at final examinations as was acknowledged by the Zimbabwe School Examination Council Examiner's Report (November, 2004). The report further noted that knowledge of techniques was limited and often mechanical, extending little beyond dot maps. Much of the learning seemed to be purely theoretical and divorced from practical activity.

From the analysis of the inventory of resources and other related documents it was noted that some teaching materials such as maps, projectors, DVD players and cassette, computers, televisions, VCRs and video cassettes were rarely used as result of power outages. This promoted teacher-directed and not problem-solving approaches yet diversification of teaching and learning is essential for motivation of students (Perrot, 1982; Graves et al, 1989; Bigala: 1996; and Tilbury and Williams: 1997).

The results from the analysis of documents and other instruments used also showed the unavailability of internet and library facilities. Neither the students nor the teachers had the opportunity of accessing current geographical information from either the internet or the library.

Lack of seminars and workshops for the continued professional development (CPD) of teachers was constantly cited during the interview as a contributory factor to the low competence of teachers despite being degree holders.

This resulted in the poor performance of students. The non-affiliation of schools and teachers to geographical associations was noted as a hitch to the teaching and learning of Human and Physical Geography. Such associations provide current and useful information which facilitates the teaching and learning of Human and Physical Geography.

\section{Conclusion}

The findings from this study revealed that students in Makonde District rural high schools found Physical Geography to be more difficult than Human Geography. They were performing better in Human than in Physical Geography from 2003 to 2006. The teachers and students faced a critical shortage of text books in the teaching and learning of Human and Physical Geography. The quantity and variety of the books was very low, making the student-text book ratio very high. This strained the teachers and made them teach with only what was available. This led to teacher-directed work instead of learner-centered activities. The schools were not receiving geographical journals and magazines where some of the issues of both Human and Physical Geography are documented. Most of the students tended to rely heavily on notes prepared by their teachers. This situation was worse with regard to Physical Geography since teachers were not adequately covering the syllabus in their teaching. Lastly, the unavailability of a school library and internet at the schools was a constraint to the teaching and learning of Human and Physical Geography. There is therefore a need for the school authorities, to address the unavailability of textbooks, libraries, internet and other teaching resources. Teachers need continual professional development through workshops and in-service seminars. They also need to make sure that they adequately cover the syllabus and practical work.

\section{Acknowledgement}

The authors wish to express their warm gratitude to the Ministry of Education, Sports Arts and Culture Head Office, Mashonaland West Provincial Office and the head teachers of the high schools studied for giving us permission to carry out this research. 


\section{REFERENCES}

Bigala, J. C. B. (1996) General Methodology: A Handbook for Teachers. Olive Publishing House, Mzuzu.

Chikoko, V. and Mhloyi, G. (1995) Introduction to Educational Research MethodsModule EA3DC101. The Centre for Distance Education, Harare.

Gay, L. R. (1976) Educational Research: Competencies for Analysis and Application. Bell and Howell Company, Columbus.

Graves, N. J., Kent, A., Lambert, D., Naish, M. and Slater, F. (1989) Research in

Geography Education: MA Dissertations 1968-1988 Institute of Education University of London. University of London Institute of Education, London.

Gwarinda, T. C. (2001) The Practice of Teaching. The College Press Publishers, Harare.

Marimo, S. T. (2005) An Evaluation of the Implementation of the new 'A' level Geography Curriculum: A Case Study of Harare High Schools. (Unpublished Masters Dissertation) University of Zimbabwe, Faculty of Education, Harare.

McMillan, J. H. and Schumacher, S. (1993) Research in Education: A Conceptual Introduction ( $3^{\text {rd }}$ Edition). Harper Collins College Publishers, New York.

Namasasu, O. and Samushonga, F. (1996) Problems of Applying Quantitative Methods in 'A' level Geography with Reference to Mutare Schools. Geographical Education Magazine Volume 19(2) 17-21

Opie, C. (2004) Doing Educational Research: A Guide to First-time Researchers. SAGE Publications, London.

Perrot, E. (1982) Effective Teaching: A Practical Guide to Improving your Teaching. Longman, New York.
Tilbury, D. and Williams, M. (1997) Teaching and Learning Geography. Routledge, London.

Tuckman, B. W. (1988) Conducting Educational Research ( $3^{\text {rd }}$ Edition). Harcourt Brace Jovanovich Publishers, Orlando.

Zimbabwe School Examination Council: General Certificate of Education (ZGCE)

Advanced Level Report on the November 2004 Examination Geography 9156.

Zimbabwe School Examination Council: General Certificate of Education (ZGCE)

Advanced Level Report on the November 2005 Examination Geography 9156. 